\title{
1. Introduction: China and North Korea: between development and security
}

\author{
Catherine Jones and Sarah Teitt
}

\section{INTRODUCTION}

In recent years, the international community, and particularly the United Nations (UN), has drawn greater attention to the tension between support and protection for the fragile population of the Democratic People's Republic of Korea or DPRK (also known as North Korea) and attempts to curtail its development of nuclear weapons, arguing that the security threats posed by the North Korean state and the insecurities confronting its citizens are inextricably linked. Up until 2014, the international community adopted separate processes and policies to address the external and internal security threats in North Korea, imposing UN sanctions to manage the external threat, and providing humanitarian aid to support a struggling population to address the internal threats. In 2014, with the publication of a UN-mandated Commission of Inquiry report into the human rights of the population in North Korea, attention was refocused on the relationship between the internal and external security environments. This re-invigorated focus raises the question of how can or should the international community, and particularly North Korea's neighbouring states, manage or mitigate the internal security threats emanating from North Korea.

Although it would be naïve to suggest this is a new question, in responding to it this book adopts a new approach. It identifies that China and the Republic of Korea (also known as South Korea) have a long history of approaching the external and internal threats as a part of the same problem, seeking to address the external threat from the regime through internal development. As such, they have both sought to support the development of the population, including their healthcare needs, food supplies and living conditions, and the national economy in North Korea, without unintentionally supporting nuclear developments. For example, 
in order to address the internal situation in North Korea, both China and South Korea consistently provided North Korea with humanitarian aid, and in 2017 they were the only states to do so. In addition, both states have sought to encourage the economic development of North Korea through the creation of special economic zones.

At the same time, in addressing the external threat posed by North Korea, both China and South Korea have enforced UN multilateral sanctions since 2006 to curtail the regime's access to goods necessary to develop its nuclear and missile programmes. In international responses to provocations from Pyongyang, since 2016 the focus has increasingly been on imposing harsher sanctions and reducing development assistance, while continuing to shine a spotlight on the human rights situation by keeping it on the agenda of the UN Security Council (UNSC). Yet, within this broad international trend, China has been cited as being out of step with the approach of some of the Security Council members, and questions have been raised concerning the nature of the support China provides to Pyongyang and the merits of Beijing's non-confrontational and developmental approach for addressing the vulnerabilities of North Korean people. In particular, it has been questioned whether China's development assistance, trade, and aid undermine the efficacy of UN sanctions.

In a summit held in Singapore on 12 June 2018 between US president Donald Trump and North Korean president Kim Jong-un, the issue of the relationship between trade, aid and sanctions was highlighted. With the joint statement stating, "the establishment of new US-DPRK relations will contribute to the peace and prosperity of the Korean Peninsula and of the world' (France 24, 2018), President Trump, in response to questions at the press statement, also highlighted the opening of trade and the opportunities for both the DPRK and the US (Channel 4 News, 2018). At the same time, President Trump dismissed human rights concerns, seeming to align the US's position closer to China's trade and development driven approach to improving the security situation with and in North Korea.

But the commentary in 2018 and 2019 on the closer alignment of the approaches of the US and China has not been matched by concrete analysis of what China's development and security approach actually is: how does China's developmental approach to peace and security inform the country's policies towards North Korea? How do Chinese actors understand the security challenges in North Korea and their role in addressing them?

This book explores the policies and practices adopted by China and how they are understood by South Korea and the US. It starts with a consideration of China's wider approach to security and investigates approaches dubbed 'developmental peace' or 'Chinese peace' as well as how China conceptualises such approaches to peace, development and security. 


\section{WHERE YOU STAND DEPENDS ON WHERE YOU SIT: WHAT KIND OF PROBLEM IS NORTH KOREA?}

North Korea is a multifaceted global security problem. It is a bundle of interrelated security challenges, encompassing a spectrum of issues including nuclear proliferation, missile development, migration, human rights, economic development, water security, energy security, environmental degradation and humanitarian assistance. And although nuclear and missile technologies present the most pressing, urgent and existential threat to regional and global security, and as a result have captured academic attention, it is the interconnection between a range of security challenges that presents the most testing problem.

In the management of the nuclear developments, sanctions have been the central tool of the international community. They have been applied with the intention of signalling inappropriate behaviour and to strategically choke off the North Korean regime's access to necessary materials and therefore halt its weapons programme (Biersteker et al., 2016; UN Document S/RES/1718 October 2006; UN Document S/RES/1874 June 2009; UN Document S/RES/2087 January 2013; UN Document S/ RES/2094 March 2013; UN Document S/RES/2270 March 2016; UN Document S/RES/2321 November 2016; UN Document S/RES/2356 June 2017; UN Document S/RES/2371 August 2017; UN Document S/ RES/2375 September 2017; UN Document S/RES/2397 December 2017). In approving, applying and evaluating these sanctions, it is noted that they should not adversely affect the population of North Korea, but instead be targeted and smart to focus on the elites and the nuclear programme (Carish et al., 2017; Drezner, 2011).

At the same time as they impose sanctions, at the national level both China and South Korea have adopted policies that provide both opportunities for economic development and humanitarian assistance to North Korea. For example, both states have continued to provide the regime in North Korea with humanitarian assistance, have sought to open special economic zones and develop non-sanctioned trade with the country, and have had to deal with population flows from the regime. China and South Korea have pursued these policies despite their potential for undermining the use of sanctions (Early, 2015:27-8).

A further security concern raised by the international community is the situation facing the population in North Korea. In 2014, the human rights situation in North Korea was brought to the table of the UNSC. Unprecedentedly, discussion in the UNSC followed the release of a report of the UN Commission of Inquiry on Human Rights in the DPRK, which was published by the UN Human Rights Council (UNHRC) and 
documented grave patterns of human rights abuses that could constitute crimes against humanity (UNHRC Document A/HRC/25/63, 2014). The report outlined two lines of engagement as potential approaches to the North Korean human rights situation. The first endorsed international punitive action, seeking to directly impose respect for human rights and punish perpetrators of crimes against humanity (with a caveat that sanctions should not be imposed that harm the population as a whole).

The Security Council should refer the situation in the Democratic People's Republic of Korea to the International Criminal Court for action in accordance with that court's jurisdiction. The Security Council should also adopt targeted sanctions against those who appear to be most responsible for crimes against humanity. (UNHRC Document A/HRC/25/63 paragraph 94a, 2014)

The United Nations High Commissioner for Human Rights, with full support from the Human Rights Council and the General Assembly, should establish a structure to help to ensure accountability for human rights violations in the Democratic People's Republic of Korea, in particular where such violations amount to crimes against humanity. (UNHRC Document A/HRC/25/63 paragraph 94c, 2014)

The second approach may be seen as the developmental approach, whereby supporting the development of the regime is a route to both regional stability and the provision of human rights for the population.

The commission of inquiry recommends that States and civil society organizations foster opportunities for people-to-people dialogue and contact in such areas as culture, science, sports, good governance and economic development that provide citizens of the Democratic People's Republic of Korea with opportunities to exchange information and be exposed to experiences outside their home country. (UNHRC Document A/HRC/25/63 paragraph 92, 2014)

States should not use the provision of food and other essential humanitarian assistance to impose economic or political pressure on the Democratic People's Republic of Korea. Humanitarian assistance should be provided in accordance with humanitarian and human rights principles, including the principle of non-discrimination. Aid should only be curbed to the extent that unimpeded international humanitarian access and related monitoring is not adequately guaranteed. Bilateral and multilateral providers of assistance should coordinate their efforts to ensure that adequate conditions of humanitarian access and related monitoring are provided by the Democratic People's Republic of Korea. (UNHRC Document A/HRC/25/63 paragraph 94i, 2014)

In the years that have followed the Commission of Inquiry report, the situation in North Korea has changed. The increased number of missile and nuclear threats has led to an extension of the sanctions against the 
regime. Pyongyang's increasing military provocations have also been met with calls for greater human rights accountability. Specifically, in 2016, the then UN Special Rapporteur on the situation of human rights in the DPRK, Marzuki Darusman, argued that 'the denial of human rights to its citizens internally has made resources available to embark on the path of aggressive military buildup; these are basically two sides of the same coin' (United Nations Office of the High Commissioner for Human Rights, 2016). At the same time, sanctions that have been authorised since 2016 have increasingly restricted access to goods provided to assist the population. As a result, the two-handed policies that previously treated improving human security and addressing threats posed by the DPRK's weapons programmes as separate policy domains have become increasingly intertwined.

The North Korea problem can be seen to encompass three aspects: (1) a security problem concerned with nuclear proliferation and threats; (2) a development challenge; and (3) a human security and protection problem. However, North Korea's problems are not discrete or separable, but rather these challenges are interrelated. Despite the wealth of academic and policy papers on this topic, each piece of research to date has tended to focus on a single element - the development of nuclear technologies, or the use and effectiveness of sanctions, or development prospects, or the issue of human rights. Yet, this approach cannot effectively deal with the interrelationships between these security issues.

This book considers an alternative approach to understanding the security threat of North Korea, by situating it within a development-security nexus. In particular, the book considers an approach in this area that has evolved from China's peacekeeping practices, namely the developmental peace or Chinese peace (Kuo, 2015), whereby conflict is mitigated through the provision of non-coercive development assistance. This approach is drawn from questions raised by the international community about the relationship between the management of the use and development of nuclear weapons and the provision of human protection to the population of North Korea. The Commission of Inquiry report on human rights in North Korea set out a number of potential policy avenues to pursue with respect to North Korea, one being the prosecution of Kim Jong-un through the International Criminal Court (ICC). However, the report also highlighted the need for development and development assistance as means of protecting this vulnerable population (UNHRC Document A/HRC/25/63 paragraph $89(1), 2014)$. In his briefing to the UNSC in December 2017, the UN Secretary-General noted that the commitment of development assistance to North Korea was about 30 per cent of the volume requested (UN Document S/PV.8137 December 2017). 
Within the three aspects of the security threat presented by North Korea (nuclear proliferation, development, human security), China's approach and relationship with the regime is perceived to be crucial. But it is also widely seen as inconsistent. In exploring China's approach to the regime, research here too has tended to deal with discrete issues, for example China's priorities (Xu and Bajoria, 2014; Margesson et al., 2007), debates within China on North Korea (for a review see: Chan and Bridges, 2018), China's potentially changing posture, or China's imposition of sanctions (Wikileaks, 2009; Jones, 2018a; Wuthnow, 2013; Zhao, 2016; Nolan, 2009:9). Yet, China's statements from its foreign ministry and in the Security Council demonstrate an increasing complexity in its dealings with Pyongyang that is positioned at the intersection of non-proliferation, development and the well-being of the North Korean people. To date there has been an absence of exploration of how China understands and pursues a policy that balances and links the development of North Korea with the protection of the population and the ambition of denuclearisation. Indeed, as China grapples with managing one aspect of the security threat, it is presented as undermining the approach of the international community in another aspect. For example, China's attempt to provide development and food to the regime is perceived as undermining the effectiveness of sanctions. Likewise, China has voiced concern for the protection of the population of North Korea, but also objects to the use of UN instruments, such as the UNSC and the UNHRC, to discuss human rights. At the same time, China is one of only three states in the world that provides development assistance to the regime in North Korea and actively seeks the development of the North Korean economy as a means of ensuring the provision of at least economic and social rights. As a consequence, China's positions on these issues have been seen as being consistently contradictory.

South Korea's position oscillates between economic engagement and economic isolation, depending on the party in power in the Blue House, as demonstrated by the different approaches adopted by President Park and President Moon. Indeed, between the two major political parties in South Korea, there was a difference as to whether the UN Office of the High Commissioner on Human Rights (OHCHR) should be positioned in Seoul or elsewhere, as there were concerns as to whether this would be seen as a provocation towards Pyongyang.

Although these different preferences within South Korea are important to the activity and type of engagement with North Korea, there are some overall commonalities between the parties in Seoul that continue to set them apart from the US and Japan. For example, even under the hard line towards engagement set by President Park, during the escalating nuclear 
tensions of September 2017 South Korea approved the delivery of aid to the North for the relief of suffering of children and pregnant women (McCurry, 2017). This policy is more akin to the approach adopted by China during this period, who also continued to provide humanitarian aid to North Korea. As a result, there is a need to explore the policies of China and how South Korea understands them - and could coordinate with them - in order to create a coherent regional policy on North Korea.

Academic discussions so far have not considered the relevance of the relationship between security and development in relation to North Korea. In this book we consider a broader approach to the North Korean security problem, by considering the threat triggers that directly affect and produce different policy preferences from the states in North East Asia. In particular, we focus on China's approach to North Korea and consider what role China plays with respect to North Korea in the areas of policy in between development and security. This issue is then broken down into sub-research questions within each of the chapters.

In our conclusion, we make the claim that while there remain some contradictions in China's approach to North Korea, which are exacerbated by the range of Chinese actors involved, considerations of China's wider developmental peace policies help to increase our understanding of China's position and policies regarding North Korea.

This finding presents an opportunity and a challenge. As an opportunity, this approach suggests that pragmatic engagement with China is possible on a number of issues, particularly in the area of water security and development assistance. However, when issues become securitised and are implemented through coordination with political and security actors, coordination is less likely, as at this level of engagement the underlying differences over abstract concepts present a barrier to cooperation.

\section{WHY LOOK AT PEACE, DEVELOPMENT AND SECURITY?}

In 2017, Jang and Suh argued that the 'nexus of security and development lies in the crux of challenges confronting human security and aid failure in North Korea' (2017:730). Indeed, in their article they claim that while the majority of the literature on North Korea focuses on nuclear and missile technologies and other security threats including human insecurity and human rights are marginalised to the periphery of the debate, the connection between these sources of insecurity lie at the heart of finding appropriate responses to the security dilemma on the Korean peninsula (Jang and Suh, 2017). Although the development-security nexus was 
developed in relation to explaining post-Cold War intra- and interstate conflicts in Africa, Jang and Suh argue that it can be readily applied to the situation in North Korea.

The idea underpinning the nexus between development and security is that international human insecurity is a driver for national insecurity. In looking at the range of concerns and national interests of China in relation to North Korea, it is clear that chief among them are concerns that can be seen as being driven by human insecurity within the DPRK rather than the threatening behaviour of the North Korean regime. In particular, the concerns of China about regional instability and large-scale flows of migrants map onto the patterns of violence and regional instability witnessed at the end of the Cold War that the development and security nexus sought to explain. This section discusses the emergence of the concept and goes on to highlight how it applies to Chinese understandings of peace and security.

\section{Concept of a Nexus between Security and Development}

The relationship between security and development, and how it can be used to further a range of policy objectives, has been a reoccurring feature of the post-2000 foreign policies of Western states. It can be seen to be a defining feature of UK Prime Minister Tony Blair's foreign policy in 2001 (The Guardian, 2001), and an understanding of this relationship between development and security has been incorporated into the documents of the $\mathrm{UN}$ and by member states of the Development Assistance Committee of the Organisation for Economic Co-operation and Development (OECD). Although this is commonly seen as the starting point for policies that bring together development and security as mutually constitutive concepts, Mark Duffield's exploration of its genealogy identifies features of this approach going as far back as Truman's 1949 speech to the UN (Duffield, 2010). In subsequent years, a literature on the nexus between security and development has increasingly seen this as a single concept, wherein development mitigates insecurities that can lead to security threats.

The concept is centred on a hypothesis that the development of weak or fragile states removes some of the drivers for conflict and as a result enhances security (Keen, 2000:37). The focus of this approach has been on the 'new wars' that have occurred since the end of the Cold War, which have primarily been seen as internal conflicts (Kaldor, 2001). The object of this approach is to provide security to, or reduce the insecurity of, domestic populations or groups. There are two schools of thought on exactly what type of insecurity should be addressed in order to achieve these outcomes. On the one hand, Japan's understanding and concept of human security has focused on the freedom from want, that is provision of food, 
subsistence, and shelter. On the other, the Canadian school developed an approach that focused on freedom from fear, which emphasised freedom from politically repressive forces and coercive violence by state and nonstate actors.

The development-security approach also engages with a broader and deeper understanding of security in seeking to identify the causes of internal conflict - whether that is scarcity of a natural resource such as water, fuel or food, what some term environmental security (HomerDixon, 1991; Dyer, 2001; Swain, 1996:970-73), or the absence of personal security. The argument goes that by taking away the drivers or causes of an internal conflict, it is also possible to reduce the risk of such conflict. This approach, although criticised by some (Cramer, 2002), has become an ideal type for non-governmental organisations (NGOs) and the UN in the pursuit of global peace and stability. For example, in 2007, Oxfam produced a report accounting for the relationship between conflict and development, indicating that during conflict 'economic activity falters or grinds to a halt' (Oxfam, 2007). In addition, in 2016, the UN launched its sustaining peace objectives (in UN Document A/RES/70/262 May 2016 and UN Document S/RES/2282 April 2016), which has since led to a high-level meeting in 2018. The aim of sustaining peace is to refocus the organisation's attention towards conflict prevention, and in so doing seek a more cost-efficient and humanitarian solution to conflict management, as it is more cost effective, has fewer negative effects on the regional economy and protects populations.

However, this approach to security has not been applied to the situation in North Korea for a number of reasons. First, the North Korea situation, or the tensions on the Korean peninsula, is not conceived as being an internal conflict, despite the fact that North Koreans continue to assert that there is only one Korea and that North Korea is the embodiment of the 'Chosen Kingdom'.

Second, although the Cold War ended in the rest of the world at the start of the 1990s, there are still arguments as to whether it (and therefore the alliance and patronage dynamics) has ended in East Asia, and in particular whether it has ended on the Korean peninsula (Wallerstein, 2010; Hara, 1999). Similarly, as Mary Kaldor sets out in defining her concept of new wars, such wars 'arise in the context of the erosion of the autonomy of the state and in some extreme cases the disintegration of the state. In particular, they occur in the context of the erosion of the monopoly of legitimate organized violence' (Kaldor, 2001:4). According to this definition, the North Korea situation cannot be seen as a new war as the state retains a monopoly on the use of violence and cannot be considered to be disintegrating. As a result, on the surface, it does not seem reasonable to 
try to understand the North Korea situation through the lens of new wars; nor does it seem valid to approach the situation from the perspective of development, as the causes of conflict are not perceived to be those that can be mitigated through development.

Third, there is a tension between an approach to North Korea that encourages development in order to support the human development capacity of the regime, and the pursuit of constraining North Korea's nuclear and missile ambitions. In December 2017, sanctions against North Korea were extended to include the export of food and agricultural products from North Korea (UN Document S/RES/2397 December 2017); previously, the DPRK had been banned from exporting textiles (UN Document S/RES/2375 September 2017). At the same time, states were required to halt the transfer of goods to and from North Korea including fish products (UN Document S/RES/2371 August 2017). Each of these bans directly affects the ability of the North Korean population to trade and develop. At the same time, they have been assumed to be partially responsible for applying sufficient pressure on the regime in Pyongyang for it to consider the process of denuclearisation.

However, this raises a question as to whether it is more appropriate to understand North Korea through the more classic security lens that considers triggers for war as including threat perception and particularly threat misperception (Levy, 1983). In these assessments of conflict, Thomas Hobbes's underlying evaluation of human nature as being of constant insecurity only mitigated by the abdication of individual sovereignty to a higher power, forms an essential element to these arguments. In this anarchic situation, North Korea seeks nuclear and missile technology in order to deter an attack by another state (principally the US), and to protect itself in the event of any deterrence failing.

This classic conceptualisation of security as being the continuation of the nation state and its defence from external attack appears to most clearly capture some of the security dynamics regarding North Korea, at least from the perspective of the US and more distant states. However, this conception of the security dynamics of North Korea does not enable an understanding of how it is possible to deal with or manage the interrelated security dilemmas presented by Pyongyang. In particular, it does not account for the threat to regional stability that is akin to the threat presented in ethnic and civil conflicts in other parts of the world, including the flow of persons across the border and the development of security risks such as those relating to water and the environment. These elements of the threat presented by Pyongyang are necessarily more localised and a greater risk to the neighbouring states of South Korea and China, and this may therefore help us to understand the two-handed approaches adopted by 
China and South Korea. Arising from this need to focus more closely on the two-handed approach by neighbouring states, the puzzle at the heart of this book seems to be partially explained by the addition of a development lens to the issue. However, for this development-security approach to be useful or even successful, greater analysis is needed using a conjoined conceptual lens.

This book identifies that these two approaches (of deterrence and development) to security have the potential to be useful in considerations of how to deal with North Korea, and in the policies of China, Japan, South Korea and the US it is possible to see evidence of both approaches. Yet, as the literature on the link between development and security has focused on civil conflict rather than transitional wars, its applicability to the North Korean situation is tenuous, particularly if the understanding of the threat is primarily that of a threatening nuclear power. Because of this, in using this concept of the development-security nexus, it is necessary to adapt the framework and assess the validity of the underpinning assumptions.

\section{China and the Developmental Peace}

China has been praised and criticised for its unique approach to peace. In particular, criticism of China's approaches to development and its noninterference policy have forced the state to consider how it can reconcile its preferred policies towards conflict-ridden or conflict-prone states to approaches acceptable to the West. In writings on this, China's approach has been branded by Steven Kuo as the 'Chinese peace' and by He Yin as the 'developmental peace'.

For Kuo, the Chinese peace is concerned with bringing Chinese ideas as well as practice into the pursuit of peace. In analysis of China's approaches to UN peace operations, China has been cited as being particularly good at logistics and medical assistance, as well as in providing highly trained and competent police troops. However, Kuo argues that a Chinese peace goes beyond the provision of structures for development and towards assisting in development through a version of the 'Beijing Model' (Kuo, 2015:165). In this model, China provides partnerships for development, sets up joint entities, and shares risks with developing states (Jones, 2018b). In presenting the concept of the Chinese peace, Kuo identifies three essential ingredients: 'sovereignty, stability, and state-directed, infrastructure-led economic development' (Kuo, 2015:166). In this approach to peace and development China seeks to fulfil its own security needs while also providing the elements needed to sustain peace.

In considering the Chinese peace in relation to the developmentsecurity nexus, there are some notable similarities, but also some points 
of divergence. In terms of similarities, China's approach is congruent with preventive diplomacy strategies, and in particular with the approach of encouraging private investors in conflict areas to contribute to conflict prevention. In relation to the role of private companies in conflict prevention, there is an argument by Virginia Haufler that rather than becoming a form of 'private sanctions', 'companies should invest or remain invested, but they should better manage the side effects of their regular business operations' (Haufler, 2004:161). Furthermore, Haufler argues that rather than sanctioning a state, or seeking to cut off engagement, companies (particularly oil companies) can be used more effectively by the international community as a tool of conflict prevention. In this approach, there is some congruence with China's approach of providing development assistance to various conflict-affected states.

However, a key area of divergence between Kuo's Chinese peace and the conflict prevention and development-security nexus work is in the role of the state. The conflict prevention literature revolves around interference in a sovereign state. Whereas China's approach centres on state-directed development, conflict prevention considers the importance of early warning systems and the potential for interference as elements in the effective execution of prevention, including fact-finding missions and evaluations of human rights compliance (Ackermann, 2003).

Another significant consideration in the Chinese peace is that China acts in accordance with its own interests, with little or no pretence (Kuo, 2015:170-71). When China provides development assistance, or when it engages in peacekeeping missions, it does so with a view to its own interests and how these interests will be satisfied through any particular venture. Hence, in considering China's role in the development-security relationship with North Korea, it is essential to understand which Chinese interests may be being satisfied, and how they may be fulfilled. Over the chapters of this book a key point concerning China's behaviour stands out: China acts the way it does in relation to North Korea in order to protect its own development and its own security, which are seemingly indivisible.

In harmony with Kuo's Chinese peace argument, the focus of He Yin's concept of 'developmental peace' is China's contribution to UN peacekeeping (2017). His work highlights the role that China is playing as the 'backbone' of peace operations and goes on to note that the rise to power represents more than just a material alteration of power distribution, but also a rise of different ideas and cultures. He Yin further notes that China's approach to development and peace is not contrary to that of international institutions but offers something slightly different. He highlights that the approach moves away from 'Western Centrism' where the end goal of 
development is not teleological. In contrast, the Chinese peace does not prescribe a fixed end goal but rather allows for a higher degree of ownership of the developing state.

A further significant feature of developmental peace, or peace through development, is highlighted by Wang Xuejun. He argues that China's approach is distinctive not only in coupling non-teleological development with the aim of peace, but in emphasising the autonomy of the developing state in directing the approach to development (Xuejun, 2018).

In the chapters of this book there are some clear overlapping findings that seem to confirm that China's developmental approach to peace is informing its engagement with the DPRK. From Liu Ming's chapter (Chapter 4) it is clear that China has not sought to be an oppressive 'big brother' to North Korea but has instead looked to give the state autonomy in determining its development - but within a framework that does not threaten China's own development and security. In exploring this claim that China has allowed for North Korean autonomy, Lee's chapter (Chapter 6) provides a deep-dive into the intersection of development and security in China's north-eastern provinces alongside the development of North Korea. In Choo's chapter (Chapter 7) there is an exploration of the processes of both securitisation and non-securitisation of certain aspects of the relationship between China and North Korea. Choo finds that the securitisation process may hamper development goals.

\section{WHY LOOK AT CHINA?}

China's relationship with North Korea is viewed as being central in managing the security threat posed by the latter. China has been seen as being North Korea's ally (a relationship that was forged in the blood of the Korean War), a partner willing and able to bust sanctions, providing oil and other goods in support of an isolated regime. At times, when sanctions have been extended, China has been lambasted with claims that it undermines the UN multilateral sanctions regime and protects the North Korean regime. Yet, at the same time, China has taken exceptional steps to condemn the actions of the regime in Pyongyang (Xinhua, 2006), and evaluations of the relationship between the two states indicate that China's influence and leverage over Pyongyang are diminishing (Chan and Bridges, 2018:23; Xiao, 2013:4-8).

China's actions, then, present a puzzle for scholars seeking to evaluate and understand the security dynamics on the Korean peninsula. On the one hand, China seeks the denuclearisation of the Korean peninsula and the protection of a vulnerable population; it has acted in accordance 
with this objective in approving and implementing sanctions authorised through the UN but has coupled these actions with statements of concern for the population. On the other hand, China also repatriates refugees from North Korea and actively prevents these refugees from accessing embassies in Beijing and other Chinese cities. Moreover, its actions produce stateless children, in contravention of international human rights laws, by not granting citizenship to the children of North Korean/Chinese citizens.

China's relationship with North Korea presents a puzzle not only for the rest of the world but also for China itself. In one off-hand comment, North Korea was referred to as a bigger headache than the South China Sea (Jones and Breslin, 2015).

As China engages with the North Korean regime and the international community across areas related to both development and security, understanding China's actions is an essential element in developing coordinated and effective policy tools to manage, mitigate and address the challenges of the Korean peninsula.

However, understanding China's approach presents a number of problems for academics and policymakers alike. Indeed, across each aspect of the security threat presented by North Korea, China appears to adopt conflicting behaviours. Regarding denuclearisation, China votes in favour of sanctions but has also been implicated in not fully enforcing them. In terms of humanitarian assistance, the volume and contents of this assistance have remained opaque. And finally, in considering human protection, despite its concerns for the population of North Korea when approving sanctions, China, in a note verbale appended to the report of the Commission of Inquiry, made it clear that they reject the authority of the commission, its findings and its collection of evidence (UNHRC Documents A/HRC/25/63, 2014; A/HRC/25/CRP.1, 2014).

\section{SIGNIFICANCE OF THIS RESEARCH}

As noted at the outset of this chapter, nuclear and missile developments in the DPRK tend to be the focus of academic discussion and wider policy debates. Yet, the question of how to effectively manage relations, or what constitutes relations, with the DPRK day by day tends to be overlooked or to be only peripheral to these discussions. Despite this, in considering the future of North Korea, security issues such as human security and survival, migration and energy are fundamental in all the scenarios that we envisage for the state, as elaborated below, and therefore more research on interactions between China and North Korea is essential. 


\section{Scenario 1 - North Korean Collapse}

China has a continuing fear that, in the worst-case scenario for North Korea where the regime collapses, large-scale flows of migrants would flee across the border. It also fears that regional instability would stymie some of China's own development trends and potentially allow US troops further north than the 38th parallel.

In exploring these fears in more detail, some of them may rest on unsubstantiated assumptions that can be - and are being - lessened by further research both within and outside of China. For example, work by Bridget Coggins et al. (2018) argues that based on modelling of the flight of Syria's population, it may take two or more years for large flows of Korean refugees to begin crossing the border into China. This would suggest that China's fears could potentially be mitigated through its own actions, along with those of the international community, in the wake of a collapse. As we argue in this book, China's primary concern is the maintenance of its own development and growth. In the north-eastern Chinese provinces development and growth are weak and heavily dependent on trade with North Korea (in non-sanctioned goods) (Reilly, 2014; Pardo, 2014). In focusing on the potential threat of refugees, concern about when they would flow over the border is only a part of the problem: trade with North Korea could collapse, undermining the development of the three closest provinces. At the same time, these provinces have many ethnically Korean citizens, therefore regional stability may be threatened through internal provincial dynamics, even in the absence of flows of refugees.

In examining the fears over instability on the peninsula, China's concerns are again driven by its primary objective to ensure and guarantee its own development and future growth. Instability in any form is a direct threat to this objective, and the collapse of the Korean regime would be particularly problematic.

\section{Scenario 2 - Status Quo with Development as a Means to Engage the Regime}

In 2018, Donald Trump and Kim Jong-un held a landmark summit in Singapore. From the press statements following this discussion it is clear that Trump's strategy for dealing with North Korea has added a developmental approach. This strategy harkens back to the sunshine policy of Kim Dae Jung in South Korea and the continued efforts of both China and South Korea to develop special economic zones in North Korea.

In the year following this summit, few commitments made by either side involved in the summit have been fulfilled. The US has continued to 
impose sanctions and withheld development aid or assistance, and North Korea has only dismantled nuclear missile sites that were either previously damaged or no longer needed. In 2019, there was a subsequent summit between Kim Jong-un and President Trump, but this was less successful than the meeting in Singapore, and at the time of writing, time was running out for the agreement on the dismantling of North Korea's missile sites.

Compared to the US's bilateral relationship with North Korea, China's engagement with the regime in Pyongyang is more firmly focused on development - as noted by Liu Ming in Chapter 4 of this volume. In line with China's approach to peacekeeping, this assistance serves a domestic Chinese interest in developing the provinces of north-east China, but also espouses a rhetoric of North Korean autonomy and sovereignty.

South Korea has also increased its focus on development and economic engagement with North Korea, including the pursuit of infrastructure projects such as the re-awakened proposals for a railway crossing the demilitarised zone (Haas, 2018).

As a result, there now appears to be an emerging strategy whereby in dealing with North Korea the focus of neighbouring states is increasingly on economic development. However, in delivering development assistance, a key difference between these states can be found in the terms and conditions they apply. In particular, specific details of the approach towards development regarding North Korea have the potential to open up fissures in the ostensibly common approach. As China is a distinctive partner here, it is timely to consider how it is approaching the delivery of development assistance to North Korea and to understand how the details of this approach are understood by both the US and South Korea.

\section{Scenario 3 - Status Quo where Development Undermines or Challenges the Regime}

The third, and most plausible, scenario for North Korea is that development and the emergence of a capitalist economy will undermine the regime and trigger a decline, a collapse or the introduction of a new form of authoritarian rule (Kim, 2019). At this point it is necessary to consider the effects of an alteration to the regime in North Korea that may result from gradual changes within the state itself.

China has consistently stated that it is against enforced regime change or deliberate actions by (Western) powers to undermine a particular regime within a state. However, through its process of 'reforming and opening up' and its engagement with the world economy and global governance, China itself has experienced some incremental domestic changes, and there have 
been suggestions that this is an approach that it has encouraged North Korea also to adopt.

The challenge is to balance the engagement so as to encourage enough domestic reform but without triggering a collapse that could cause regional instability. Reform in this case could take a number of forms, and in discussing and specifying them it is vitally important to consider: the actors or agents involved; the scale and scope of the engagement; and the underpinning logics and assumptions of the participants. The analysis in this book on current relations between North Korea and China therefore provides a rigorous exploration across these elements in terms of both the historical relationship and their current relations.

In considering these three scenarios - without preferencing or prophesying any one in particular - this book is well positioned to provide a wider understanding of China's approach to North Korea, but also to provide a more detailed understanding of the perceptions of those activities by other state players.

\section{STANDARDS AND TYPES OF EVIDENCE USED IN THE CHAPTERS}

One of the pervasive challenges of researching North Korea (and at times China) is the lack of verifiable evidence. In this book we have sought to diversify the types of evidence used and seek contributions from scholars within South Korea and China in order to ensure that we genuinely reflect both the academic and policy positions. In each of the chapters there is reflection on the evidence that has been used and the relative strengths and weaknesses of the available material.

Within each chapter the authors have drawn on a range of sources. The resources used range from agreements between China and North Korea over transboundary water relations, North Korean documents about the development assistance provided by China, to evidence from international NGOs and institutions. Each chapter contains clear referencing, making it possible to trace the resources used.

\section{STRUCTURE OF THE BOOK}

This book is organised into three parts: the conceptual apparatus; ChinaNorth Korea relations; and regional understandings of China-North Korea relations. The conceptual part consists of two essential conceptual chapters. First, in Chapter 2 Sarah Teitt discusses Chinese understandings 
of peace, development and security. The chapter explores China's 'developmental approach' to peace and security in the context of its responses to North Korea's military and human security challenges. It begins with an overview of China's unique understanding of the development-security nexus, which views state-led economic development with minimal external political interference and strong state control over society as the path to long-term peace, state and regional stability, and human security. The chapter then explains how Chinese perspectives on development and security guide China's approach towards international conflict management, humanitarian and development assistance, and human rights protection. The final section in the chapter examines how these insights help explain China's 'trade and aid' approach to reducing the North Korean military threat and enhancing the well-being of the North Korean people.

In the second conceptual chapter, Chapter 3, Catherine Jones outlines the different actors involved in China's relations with North Korea. The chapter presents the argument that when considering these different actors, evaluations of China's role in promoting peace and security change markedly, as do considerations of the prospects for concerted regional action. She seeks to further open the black box of actors involved and outlines the different potentials for positive engagement.

The next part of the book takes three different approaches to understanding China-North Korea relations. Liu Ming's chapter, Chapter 4, adopts a historical approach, considering the different phases of the relationship between these two states. He identifies that during the Cold War, China and North Korea were traditional security partners, and this relationship was based on three elements: (1) China's participation in the Korean War, (2) having the same ideology, and (3) Beijing's commitment to protect Pyongyang's security via a Treaty of Friendly Mutual Assistance. This allied relationship became more in name only during the post-Cold War era, particularly after China's own policy of opening up and its establishment of diplomatic relations with South Korea in 1992. However, Beijing has not totally transformed the bilateral relationship into a normal state one, and even now the relationship is complicated: neither allies, nor close friends, nor ordinary neighbours. The reasons behind this long-maintained relationship are the complex emotions and friendships inherited from the first and second generations of leaders, and the traditional sympathy towards North Korea among some Chinese officials and officers. Liu Ming's analysis contributes to finding a more accurate representation of this relationship. He argues that China and North Korea should not simply be conceptualised as 'friends' or 'allies'.

Building on this historical analysis, Zheng Jiyong and Wang Xingxing's chapter, Chapter 5, explores in more detail the types of development 
assistance that China provides to North Korea. The authors outline that China is a leading provider of development assistance to the DPRK, contributing to areas of food, medical and human security. In the event of a humanitarian crisis, China's assistance will be crucially important. Despite the level of engagement compared with the rest of the international community, for China these humanitarian and development concerns remain secondary to the issues of nuclear and traditional security, and China remains focused on maintaining its own development and security. As a result, the subject of security in these areas is not just North Korea but also China and the wider region, and these humanitarian and development issues are only one part of a larger security challenge. These issues, however, can provide some useful points of engagement. In the chapter Zheng and Wang use evidence collected in China from both North Korean and Chinese sources. These materials then provide a key insight into the understandings of both China and North Korea regarding the situation and how they individually seek to manage it.

The final chapter of this part, Chapter 6, explores a specific case of China-North Korea relations, namely the issue of transboundary water relations. In his chapter, Seungho Lee evaluates the relationship between China and North Korea over water resources management in the Yalu/ Amrok River, which serves as an international border. Primary attention is paid to the period after the truce of the Korean War in 1953. Since then, the two communist countries have closely collaborated on many aspects relating to water, particularly in utilising the vast amounts of water resources available in the Yalu/Amrok River Basin. The fundamental elements of transboundary water relationships between China and North Korea have been enshrined in their common political ideology as well as security aspects, and as a consequence of these commonalities their interactions relating to water have also been developmental.

The chapter argues that the case of water management between China and North Korea reveals several things about the relationship between these two 'brothers'. First, transboundary water issues in this river basin are not only tied to water resources management but are also tied to the peculiar power asymmetry between the countries in politics and economy. Second, China uses development approaches to enhance security on the peninsula. Third, development and security in relation to water serves not only the interests of the North Korean population but also the vital development and security needs of China.

The final part of the book explores how interactions between China and North Korea have been understood in both South Korea and the US. Jaewoo Choo's chapter, Chapter 7, explores an apparent contradiction in China's approach to North Korea. In the arguments it presents in the 
UNSC against tougher sanctions for the DPRK, and in its action in voting against UNHRC resolutions against North Korea, China highlights that international activities should not harm the well-being of ordinary North Korean people. However, China does not appear to act in accordance with these arguments. In investigating this tension, this chapter first evaluates whether there is actual consistency or just the appearance of consistency between China's statements on development-security statements and its actions. Then it makes an assessment of whether there are opportunities for other states to engage with China's actions, or conversely, barriers to such engagement. Choo concludes that there is significant inconsistency between understandings or expectations of China derived from public statements and its private actions, and this, along with China's securitisation of these issues, presents a barrier to cooperative and productive political and security-level engagement with China in these areas. Furthermore, he concludes that China's actions in this area have failed to generate wider engagement by the international community in support of humanitarian assistance for the regime, and that China's reasons for assisting are largely driven by concerns for its own development and security.

Jihwan Hwang's chapter, Chapter 8, focuses attention on the thorny issue of human rights and the role of China in protecting the population of North Korea. China's approach to this issue presents challenges of coordination and understanding for international partners. Hwang argues that there are three areas that are of grave concern to the international community in respect to China's relationship with North Korea. First, there are hundreds of thousands of North Koreans residing in China who have defected from their motherland. China has viewed them not as political or economic defectors but as illegal temporary immigrants seeking food, who plan to go back to North Korea as soon as possible. Second, the situation in the concentration camps in North Korea has been extensively revealed to the public, but China does not care much about this issue and considers it to be an internal issue for North Korea in which it will not interfere. Third, China has been interested in providing humanitarian assistance to North Korea and has supplied food and material over a long period in spite of the sanctions that are in place. Even when China agreed to UN sanctions on North Korea, it did not want sanctions to lead to excessive hardship for the North Korean people and so continued providing assistance. Having outlined these concerns, Hwang compares this approach of China to that of South Korea, which has demonstrated a strikingly different approach to that of China. He seeks to find out how China and South Korea can cooperate in addressing the human right concerns related to North Korea.

The conclusion contained in Chapter 9 of this book highlights the variability and complexity of the relationship between China and North 
Korea in the grey areas between development and security. In it we pull out several themes that have emerged from the chapters, including the importance of applying a Chinese framework when analysing China's approach and policies.

\section{REFERENCES}

Ackermann, Alice (2003), 'The idea of conflict prevention', Journal of Peace Research, 40 (3), 339-47.

Biersteker, Thomas J., Marcos Tourinho and Sue Eckert (2016), 'Thinking about United Nations targeted sanctions', in Thomas J. Biersteker, Sue Eckert and Marcos Tourinho (eds), Targeted Sanctions: The Impacts and Effectiveness of United Nations Action, Cambridge: Cambridge University Press, pp.11-37.

Carish, Enrico, Lorraine Rickard-Martin and Shawna R. Meister (2017), 'From comprehensive to smart and fairer sanctions', in The Evolution of UN Sanctions: From Tool of Warfare to Tool of Peace, Security and Human Rights, Cham: Springer, pp.51-65.

Chan, Che-po and Brian Bridges (2018), 'Divergence and diversity: Changing Chinese perceptions of North Korea under Kim Jong-un', Journal of Contemporary China, 27 (109), 16-31.

Channel 4 News (2018), 'President Donald Trump's full Singapore press conference after historic North Korea summit', accessed 18 June 2018 at https://www.youtube .com/watch?v=1sGxi8Yv_vQ.

Coggins, Bridget, Sara Lafia and Behzad Vahedi (2018), 'Dramatic change in North Korea: Instability and human flight propensity', North Korean Review, 14 (1), 49-70.

Cramer, C. (2002), 'Homo economicus goes to war: Methodological individualism, rational choice, and the political economy of war', War Development, 30 (11), 1845-64.

Drezner, Daniel (2011), 'Sanctions sometimes smart: Targeted sanctions in theory and practice', International Studies Review, 13 (1), 96-108.

Duffield, Mark (2010), 'The development-security nexus in historical perspective: Governing a world of peoples', in J. Sorensen (ed.), Challenging the Aid Paradigm:

Western Currents and Asian Alternatives, Basingstoke: Palgrave Macmillan, pp.25-46.

Dyer, Hugh (2001), 'Environmental security and international relations: The case for enclosure', Review of International Studies, 27 (3), 441-50.

Early, Bryan (2015), Sanctions Busted: Explaining Why Economic Sanctions Fail, Stanford, CA: Stanford University Press.

France 24 (2018), 'President Trump and President Kim's joint statement at the Singapore summit', accessed 12 June 2018 at http://www.france24.com/en/201806 12-singapore-summit-trump-kim-usa-north-korea-read-full-text-joint-statementnuclear.

Haas, Benjamin (2018), 'Railway diplomacy: South Korean trains venture north for first time in a decade', The Guardian, accessed 29 January 2019 at https://www. theguardian.com/world/2018/nov/30/south-korean-trains-venture-north-for-firsttime-in-a-decade. 
Hara, Kimie (1999), 'Rethinking the Cold War in the Asia-Pacific', The Pacific Review, 12 (4), 515-36.

Haufler, Virginia (2004), 'International diplomacy and the privatization of conflict prevention', International Studies Perspectives, 5 (2), 158-63.

Homer-Dixon, Thomas F. (1991), 'On the threshold: Environmental changes as causes of acute conflict', International Security, 16 (2), 76-116.

Jang, Suyoung and Jae-Jung Suh (2017), 'Development and security in international aid to North Korea: Commonalities and differences among the European Union, United States, and South Korea', The Pacific Review, 30 (5), 729-49.

Jones, Catherine (2018a), 'Sanctions to signal, constrain, and coerce' in 'Roundtable: Impact of sanctions on North Korea', Asia Policy, 13 (3), 20-28.

Jones, Catherine (2018b), China's Challenge to Liberal Norms: The Durability of International Order, Basingstoke: Palgrave Macmillan.

Jones, Catherine and Shaun Breslin (2015), 'China in East Asia: Confusion on the horizon?', in Jamie Gaskarth (ed.), Rising Powers, Global Governance and Global Ethics, Abingdon: Routledge, pp.115-32.

Kaldor, Mary (2001), New and Old Wars: Organized Violence in a Global Era, Cambridge: Polity Press.

Keen, David (2000), 'Aid may reduce the need for civilians to turn to violence in pursuit of sustenance', in Mats Berdal and David Malone (eds), Greed and Grievance: Economic Agendas in Civil Wars, Boulder, CO: Lynne Reinner, pp.19-41.

Kim, Byung-Yeon (2019), 'North Korea's marketisation', presentation at Chatham House, 25 January 2019.

Kim, Suki (2015), Without You, There Is No Us: My secret life teaching the sons of North Korea's elite, London: Penguin, Random House.

Kuo, Steven (2015), 'Chinese peace? An emergent norm in African peace operations', China Quarterly of International Strategic Studies, 1 (1), 155-81.

Levy, J. (1983), 'Misperception and the causes of war: Theoretical linkages and analytical problems', World Politics, 36 (1), 76-99.

Margesson, Rhona, Emma Chanlett-Avery and Andorra Bruno (2007), North Korean refugees in China and Human Rights Issues: International Response and U.S. Policy Options, CRS Report for Congress.

McCurry, Justin (2017), 'South Korea approves \$8m aid package for North Korea', The Guardian, accessed 23 July 2018 at https://www.theguardian.com/world/2017/ sep/21/south-korea-approves-8m-aid-package-for-north-korea.

Nolan, Marcus (2009), 'The (non-) impact of UN sanctions on North Korea', East-West Centre Working Papers No. 98.

Oxfam (2007), Africa's Missing Billions, Oxfam Report No. 107, accessed 18 June 2018 at https://www.oxfam.org/sites/www.oxfam.org/files/africas $\% 20$ missing $\% 20$ bils.pdf.

Pardo, Ramon Pacheco (2014), 'Dandong and Sinuiju: The Sino-North Korean border shadow economy', in Leila Simona Talani, Alexander Clarkson and Ramon Pardo (eds), Dirty Cities: Towards a Political Economy of the Underground in Global Cities, Basingstoke: Palgrave Macmillan, pp.89-109.

Reilly, James (2014), 'The curious case of China's aid to North Korea', Asian Survey, 54 (6), 1158-83.

Swain, Ashok (1996), 'Environmental migration and conflict dynamics: Focus on developing regions', Third World Quarterly, 17 (5), 959-73. 
The Guardian (2001), 'Full text: Tony Blair's speech (part one)', accessed 18 April 2018 at https://www.theguardian.com/politics/2001/oct/02/labourconference.labour6.

UN Document, A/RES/70/262 May 2016.

UN Document, S/PV.8137, December 2017.

UN Document, S/RES/1718 October 2006.

UN Document, S/RES/1874 June 2009.

UN Document, S/RES/2087 January 2013.

UN Document, S/RES/2094 March 2013.

UN Document, S/RES/2270 March 2016.

UN Document, S/RES/2282 April 2016.

UN Document, S/RES/2321 November 2016.

UN Document, S/RES/2356 June 2017.

UN Document, S/RES/2371 August 2017.

UN Document, S/RES/2375 September 2017.

UN Document, S/RES/2397 December 2017.

UNHRC Document, A/HRC/25/63, 7 February 2014, extended report, A/HRC/25/ CRP.1, 7 February 2014.

United Nations Office of the High Commissioner for Human Rights (2016), 'Efforts to hold DPRK's leadership accountable must continue - UN expert urges in last report', accessed 16 December 2019 at http://www.ohchr.org/EN/NewsEvents/ Pages/DisplayNews.aspx?NewsID=17218\&LangID=E.

Wallerstein, Immanuel (2010), 'What Cold War in Asia? An interpretive essay', in Zheng Yangwen, Hong Liu and Michael Szonyi (eds), The Cold War in Asia: The Battle for Hearts and Minds, Leiden: Brill, pp.15-24.

Wikileaks (2009), 'China unlikely to fully implement sanctions on North Korea: A view from Shanghai', accessed 21 November 2017 at https://wikileaks.org/plusd/ cables/09SHANGHAI257_a.html.

Wuthnow, Joel (2013), 'How China reads North Korea', National Interest, accessed 16 December 2019 at http://nationalinterest.org/commentary/how-china-reads-no rth-korea-9009? page $=1$.

Xiao, Ren (2013), 'Rowing together: A Chinese perspective', Issues and Insights, 13 (9), iv-15.

Xinhua (2006), 'China resolutely opposes DPRK nuclear test', accessed 26 June 2017 at http://news.xinhuanet.com/english/2006-10/09/content_5180203.htm.

$\mathrm{Xu}$, Beina and Jayshree Bajoria (2014), 'The China-North Korea relationship', Council on Foreign Relations Backgrounder, accessed 16 December 2019 at http:// www.cfr.org/china/china-north-korea-relationship/p11097.

Xuejun, Wang (2018), 'Developmental peace: Understanding China's Africa policy in peace and security', in Chris Alden, Abiodun Alao, Zhang Chun and Laura Barber (eds), China and Africa, Cham: Palgrave Macmillan, pp.67-82.

Yin, He (2017), 'Peaceful development: Building of China's peacekeeping strategy' [发展和平:联合国维和 建和中的中国方案], International Political Studies, 4, 10-32.

Zhao, Li-Xin (2016), 'Irrelevant sanctions: An analysis of the "bottleneck" in China-DPRK relations', Journal of Yanbian University, 49 (1), 9-18. 